\title{
PROTEINURIA FOLLOWING MOMENTARY VASCULAR CONSTRICTION
}

\author{
By LEON C. CHESLEY, IRWIN MARKOWITZ, AND BENJAMIN B. WETCHLER \\ (From the Departments of Biochemistry and Urology, Margaret Hague Maternity Hospital, \\ Jersey City)
}

(Received for publication September 1, 1938)

Vasoconstriction in the glomerular and preglomerular blood vessels of the kidney with a consequent anoxia in the capillaries has been hypothesized as a cause of many proteinurias, not only in non-nephritic but even in acute nephritic conditions. The main evidence for this hypothesis is that many of the stimuli producing proteinuria are known also to interfere with the renal circulation, usually by causing vasoconstriction. However, because of the prolonged time element, and the administration of drugs, many of the earlier experiments have not been suffciently swiftly executed to rule out possible causes other than vascular spasm per se. In some cases, vascular constriction, though probable, has not been shown to have occurred.

The literature is amply reviewed by Senator (1), Volhard (2), and Fishberg (3), and will not be detailed here. Some of the difficulties of interpretation will be merely indicated.

Johnson (4), Abesser (5), Christensen (6), and others found proteinuria in many of their subjects who had swum in cold water. Since cooling the skin causes renal vascular spasm, (Wertheim (7)), the proteinuria has been attributed to vasoconstriction. But Jehle (8) and Abesser (5) explain this proteinuria by the markedly lordotic posture assumed in swimming. Still another possibility is that the increased intraabdominal pressure retards the venous return from the kidney, thereby causing proteinuria (3).

Schlombka (9) produced proteinuria in 9 of 37 subjects by immersing the lower parts of their legs in cold water for periods up to 25 minutes (average 16 minutes). He considered two possible causes; first, vascular spasm, and second, the local production in the chilled skin of some substance which affected glomerular permeability. $\mathrm{He}$ found that if the venous return from the legs was prevented, there was less proteinuria. Some subjects showed no effect from chilling alone, when the venous blood was occluded. This might be considered as favoring the second explanation.

Starr (10) produced proteinuria by the administration of adrenalin and ephedrine. Unless there was a rise in blood pressure (vasoconstriction) no proteinuria resulted. Starr found proteinuria after $\mathrm{CO}_{2}$ inhalation and hemorrhage, which also produce vasoconstriction. Cats excreted protein when excited. He believes that the vascular constriction causes an increase in the duration and extent of the normal intermittent interruptions in the glomerular circulation. Permeability of the glomerular membranes is so increased by these lengthened interruptions that when the blood flow is reestablished, protein escapes. Hermann (11) had long before shown that mechanical interruption of the renal blood flow results in proteinuria when the circulation is restored.

Orthostatic proteinuria seems to occur predominantly in individuals with labile vasomotor systems (3), and may depend upon the vascular instability (12).

In studying the vascular instability of patients with primary hypertension, Hines and Brown (13) have developed a "cold pressor test." This test consists in determining the subject's basal blood pressure after a period of rest in bed. One hand is then immersed in ice water for one minute. The blood pressure will usually rise abruptly, and is nearly maximal within 30 seconds. The magnitude of the rise in pressure varies from patient to patient, and may be very marked in some individuals. Venous stasis does not prevent the effect which apparently is reflex. The abrupt increase in pressure with a rapid return to the basal level must, of course, depend upon transitory vascular constriction.

This response to the cold pressor test is given by many apparently normal individuals in whom no renal disease or hypertension can be found. The vascular spasm, in these subjects, occurs 
within 60 seconds and disappears within the next 60 seconds as shown by the excursion of the blood pressure. Here, then, is a means of producing a momentary vascular spasm. Will such a tranisient spasm be followed closely by proteinuria? If so, the experiments would be good evidence for the hypothesis that vascular spasm does result in protein leakage.

\section{MATERIAL AND METHODS}

In the course of a study of the cold pressor test in more than 500 pregnancies (14) it was found that in 12 per cent of all the women observed the blood pressure rose more than $25 \mathrm{~mm}$. $\mathrm{Hg}$ when the cold stimulus was given. Some of these "hyper-reactors" have been used in this investigation. The patients were in varying stages of pregnancy and puerperium, and a few were several months postpartum when the present experiments were made. A control series of patients giving blood pressure rises of less than $20 \mathrm{~mm}$. $\mathrm{Hg}$ was utilized. In both groups, patients were selected both with and without preexisting proteinuria, with and without toxemia of pregnancy, and with and without demonstrable renal disease.

During the morning of the test, the patients were allowed to have breakfast, and were encouraged to take copious amounts of fluids. Ureteral catheterization was then done by one of us. Indigo carmine was injected intravenously, and the efficiency of the kidneys in excreting it was noted. The procedure was explained to all of our patients in order to minimize nervous tension. No sedative drugs were used.

On returning to bed, the patients were left for varying periods until the blood pressure had become stabilized at an apparently basal level. Two urine specimens were then obtained from each ureteral catheter, usually over 4-minute periods; these served as the controls. The hand was then immersed up to the wrist in ice water for one minute, while the blood pressure was taken at 30 and 60 seconds, and every minute thereafter. Successive urine collections were then made, in graduated centrifuge tubes, at 4-minute intervals. In many cases, the venous return from the chilled hand was prevented by a tourniquet.

Grossly bloody urine was discarded. The urine for analysis was centrifuged, first at 1200 , then at 2500 r.p.m. for about 30 minutes. Five-tenths to $2 \mathrm{ml}$. of the supernatant urine was then pipetted into centrifuge tubes, diluted to about $10 \mathrm{ml}$. with distilled water, and the protein precipitated by the addition of $2 \mathrm{ml}$. each of 10 per cent sodium tungstate and $2 / 3 \mathrm{~N}$ sulfuric acid (15). After standing overnight, the tubes were centrifuged and the supernatant fluid drained off. The protein was redissolved in 10 per cent sodium tungstate, and the precipitation repeated. The following day, the protein was dissolved in dilute sodium hydroxide and transferred quantitatively to Folin nonprotein nitrogen tubes. Digestion was accomplished by the Wong persulphate method (15), and the digest nesslerized directly and read colorimetrically against standards containing from 0.05 to $0.25 \mathrm{mgm}$. of nitrogen.

In some cases, an approximate measurement of the glomerular filtration was attempted by determining the plasma clearance of endogenous creatinine (16). The creatinine of both plasma and urine was determined by the methods of Folin (17).

\section{RESULTS}

The subjects used in this study have been divided into two groups, those who gave no response in proteinuria and those who did. The findings for the first group are abstracted in Table I. These 24 patients, with 2 exceptions,

TABLE I

Proteinuria in control series of patients who showed either no proteinuria or no increase in proteinuria after the cold pressor test *

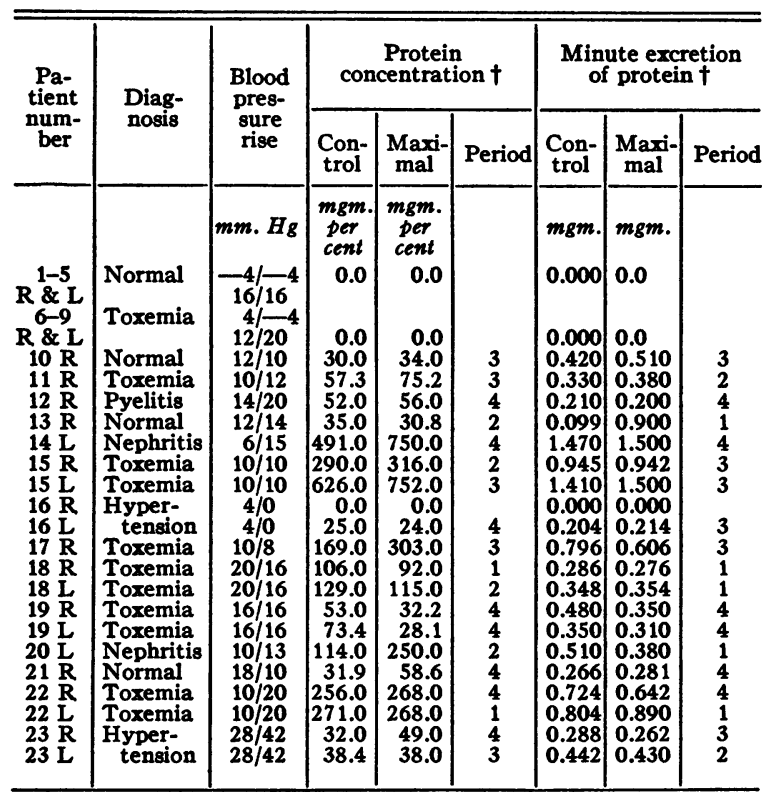

* Only two of these gave rises of more than $16 / 16 \mathrm{~mm}$. in blood pressure.

$t$ "Control" is average of two urines taken before cold stimulus. "Period" refers to the 4-minute interval in which observation is recorded. " $R$ " stands for the right kidney and " $L$ " for the left. "Maximal" is the highest proteinuria observed after the administration of the cold stimulus.

had but small increases in blood pressure following the cold pressor test; none showed any increase in protein excretion. In some cases the protein concentration in the urine increased, but this was counterbalanced by decreased urine volume. The changes in minute volume output of urine seem to be of no significance. In some cases marked increases in volume occurred, in 
some marked decreases, while in many the variations were only slight. The subjects in this group were all women ranging from the third month of pregnancy to the third month after delivery. Some were normal pregnancies, some were toxemic. One patient had pyelitis, and three were thought to have permanent hypertension. One-third of the group had no proteinuria at all prior to the test, while the other two-thirds had some degree of proteinuria ranging from faint traces to $\mathbf{5}$ grams per liter.

The patients of this first group may be taken as controls; they gave only slight vascular constriction, as shown by the blood pressure rises which average $9 / 10 \mathrm{~mm}$. $\mathrm{Hg}$ systolic/diastolic, and following the stimulus there was no increased proteinuria.

In Table II are shown the significant results obtained in 23 equally diverse subjects whose blood pressure rises were in excess of $16 / 16$.

TABLE II

Proteinuria in series of patients who gave more marked responses to the cold pressor test. All other conditions as in control series. Column heads and abbreviations as in Table I.

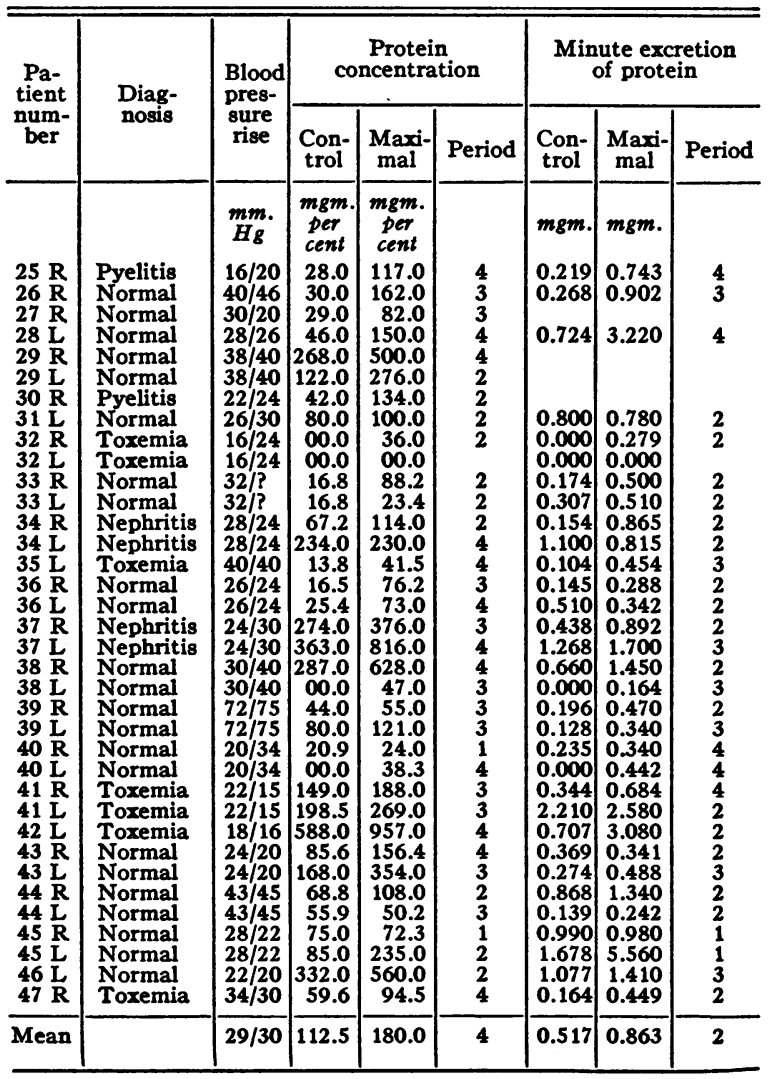

All of these patients showed an increase in proteinuria subsequent to the application of the cold stimulus. (Two patients giving such blood pressure rises did not excrete increased amounts of protein; they are included in Table I.) In 3 cases there was no preexisting proteinuria, but following the blood pressure rise, proteinuria appeared. In the other 20 cases, the original protein excretion was increased. Five subjects developed proteinuria from one kidney but not from the other. In these 23 patients 36 kidney urine series were analyzed. All but 5 series showed increased concentration of protein. Six failed to show an increased excretion (volume $X$ concentration). Of these 6 series, in 5 cases one kidney gave an increased proteinuria while the other did not. In the sixth case the urine from only one kidney was analyzed.

The average responses in the minute urine volume output, urine protein concentration, and minute excretion of protein are shown in Figure 1.

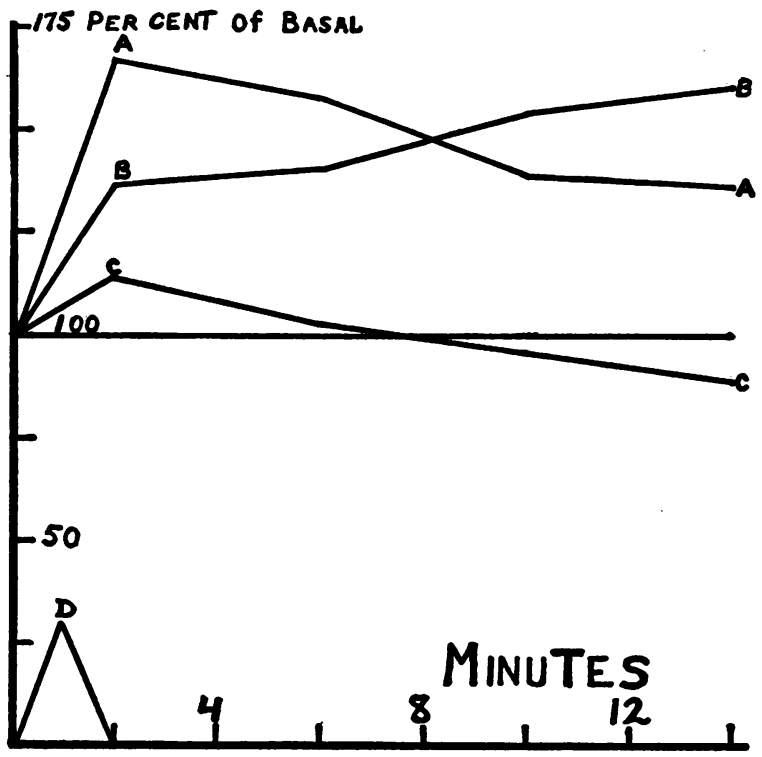

Fig. 1. The Changes in Urine Volume Output, Urine Protein Concentration, and Minute OUtPut of Protein Following Vascular Constriction

$A=$ Minute excretion of protein

$\mathrm{B}=$ Concentration of urine protein

$\mathrm{C}=$ Urine volume output

All are plotted as percentages of the basal (control) levels, which are taken as 100 per cent.

$\mathrm{D}=$ Average change in blood pressure, in $\mathrm{mm}$. $\mathrm{Hg}$

Absolute values are given in Table II. 
It is barely possible that this production of proteinuria is more apparent than real. For instance, it might be argued that not all of the urine drains through the ureteral catheters in the control periods, some escaping down the ureters. This would give false low basal proteinurias. Following the cold stimulus, the ureters might contract with a consequent diversion of more urine to the catheters, thereby apparently increasing the protein excretion. This cannot be the case in the three instances where proteinuria appeared for the first time after the cold stimulus was applied (32R, 38L, and 40L, Table II).

To control the possibility that incomplete collections of urine were vitiating the results, a series of experiments was done in which the proteinuria was calculated on the basis of the minute excretion of creatinine. If the urine collections were complete, this relates the protein excretion to the glomerular filtration (16). If the urine collections were not quantitative, the error of collection is neutralized by comparing the proteinuria with the creatinine excretion, since the ratio gives the relative amounts of protein and creatinine filtered. Table III shows the results of the experiments in which simultaneous measurements of protein and creatinine excretion were made. This ratio of protein excretion to creatinine excretion is independent of errors in urine collection and establishes the validity of the conclusion that vascular constriction is followed by increased protein leakage. In 8 of 12 cases, the ratios denoting the relative filtration of protein are markedly increased, while in 2 others they are slightly increased. The averages are represented graphically in Figure 2.

Assuming accurate collection of urine, the fluid volume filtered seems to diminish following the vascular constriction produced by the cold stim-

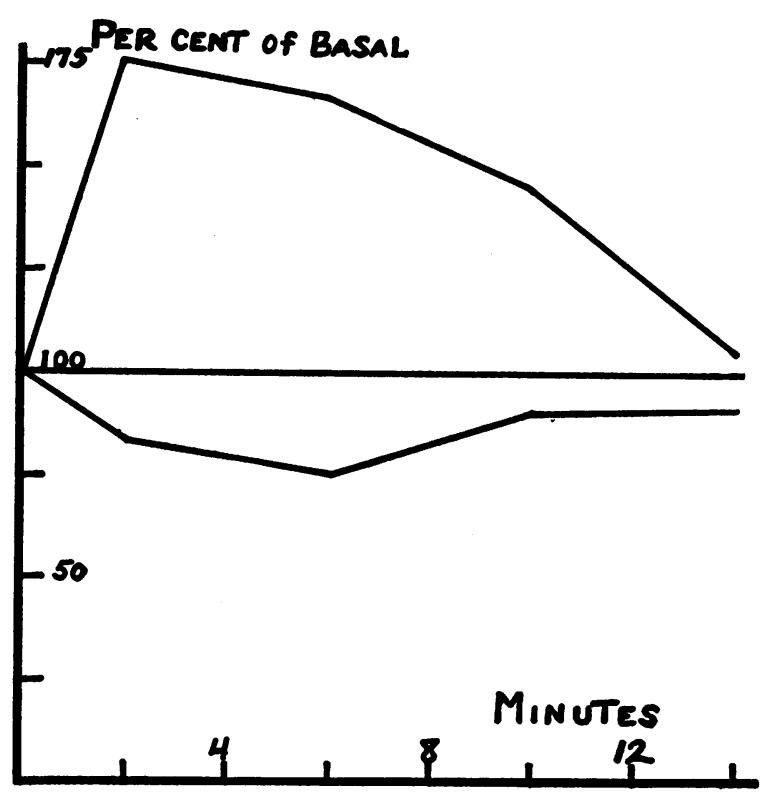

Fig. 2. The Changes in Glomerular Filtration (Lower Curve) aNd in the Protein Excreted per Unit of Glomerular Filtration (UPPer Curve)

Both curves plotted as percentages of basal (control) levels which are taken as 100 per cent. Absolute values are given in Table III.

TABLE III

The increased glomerular filtration of urine protein in subjects giving appreciable blood pressure rises after cold stimulus

\begin{tabular}{|c|c|c|c|c|c|c|c|c|c|c|c|c|c|c|c|}
\hline \multirow{2}{*}{$\begin{array}{l}\text { Patient } \\
\text { number }\end{array}$} & \multicolumn{5}{|c|}{ Minute excretion of protein } & \multicolumn{5}{|c|}{ Minute excretion of creatinine } & \multicolumn{5}{|c|}{ Protein/creatinine } \\
\hline & Control & 1 & 2 & 3 & 4 & Control & 1 & 2 & 3 & 4 & Control & 1 & 2 & 3 & 4 \\
\hline $\begin{array}{l}23 \mathrm{~L} \ldots \ldots \\
39 \mathrm{R} \ldots \ldots \\
40 \mathrm{R} \ldots \ldots \\
40 \mathrm{~L} \ldots \ldots \\
41 \mathrm{R} \ldots \ldots \\
43 \mathrm{R} \ldots \ldots \\
43 \mathrm{~L} \ldots \ldots \\
44 \mathrm{R} \ldots \ldots \\
44 \mathrm{~L} \ldots \ldots \\
45 \mathrm{R} \ldots \ldots \\
45 \mathrm{~L} \ldots \ldots \\
46 \mathrm{~L} \ldots \ldots\end{array}$ & $\begin{array}{c}\text { mgm. } \\
0.442 \\
0.196 \\
0.235 \\
0.000 \\
0.344 \\
0.369 \\
0.274 \\
0.878 \\
0.139 \\
0.990 \\
1.678 \\
1.077\end{array}$ & $\begin{array}{c}\text { mgm. } \\
0.253 \\
0.470 \\
0.312 \\
0.000 \\
0.436 \\
0.251 \\
0.395 \\
1.340 \\
0.242 \\
0.980 \\
5.560 \\
1.680\end{array}$ & $\begin{array}{l}m g m . \\
0.357 \\
0.220 \\
0.270 \\
0.245 \\
0.626 \\
0.341 \\
0.252 \\
0.920 \\
0.169 \\
0.594 \\
4.310 \\
1.060\end{array}$ & $\begin{array}{l}m g m . \\
0.430 \\
0.264 \\
0.308 \\
0.405 \\
0.659 \\
0.300 \\
0.488 \\
0.974 \\
0.094 \\
\\
2.760 \\
1.410\end{array}$ & \begin{tabular}{|c|} 
mgm. \\
0.380 \\
0.402 \\
0.340 \\
0.442 \\
0.684 \\
0.432 \\
0.319 \\
0.765 \\
0.167 \\
\\
2.150 \\
1.036
\end{tabular} & \begin{tabular}{l|} 
mgm. \\
0.311 \\
0.310 \\
0.405 \\
\\
0.235 \\
0.150 \\
0.085 \\
0.379 \\
0.104 \\
0.324 \\
0.422 \\
0.414
\end{tabular} & $\begin{array}{l}\text { mgm. } \\
0.266 \\
0.672 \\
0.350 \\
\\
0.230 \\
0.091 \\
0.072 \\
0.362 \\
0.183 \\
0.226 \\
0.373 \\
0.375\end{array}$ & $\begin{array}{l}m g m . \\
0.292 \\
0.350 \\
0.335 \\
0.275 \\
0.207 \\
0.130 \\
0.043 \\
0.213 \\
0.167 \\
0.204 \\
0.386 \\
0.297\end{array}$ & \begin{tabular}{|l} 
mgm. \\
0.402 \\
0.310 \\
0.350 \\
0.233 \\
0.211 \\
0.116 \\
0.058 \\
0.355 \\
0.072 \\
\\
0.443 \\
0.354
\end{tabular} & \begin{tabular}{|c|} 
mgm. \\
0.405 \\
0.942 \\
0.340 \\
0.162 \\
0.246 \\
0.145 \\
0.048 \\
0.298 \\
0.154 \\
\\
0.468 \\
0.304
\end{tabular} & $\begin{array}{l}1.42 \\
0.63 \\
0.58 \\
0.00 \\
1.46 \\
2.46 \\
3.22 \\
2.32 \\
1.34 \\
3.06 \\
4.00 \\
2.61\end{array}$ & $\begin{array}{r}0.96 \\
0.70 \\
0.89 \\
0.00 \\
1.90 \\
2.75 \\
5.52 \\
3.71 \\
1.32 \\
4.33 \\
14.90 \\
4.48\end{array}$ & \begin{tabular}{|r|}
1.22 \\
0.63 \\
0.81 \\
0.89 \\
3.03 \\
2.62 \\
5.84 \\
4.32 \\
1.01 \\
2.91 \\
11.17 \\
3.57
\end{tabular} & $\begin{array}{l}1.07 \\
0.82 \\
0.88 \\
1.74 \\
3.12 \\
2.59 \\
8.44 \\
2.74 \\
1.31 \\
6.24 \\
3.99\end{array}$ & $\begin{array}{l}0.94 \\
0.42 \\
1.00 \\
2.72 \\
2.78 \\
2.97 \\
6.59 \\
2.57 \\
1.09 \\
4.58 \\
3.41\end{array}$ \\
\hline Average... & 0.552 & 0.993 & 0.780 & 0.736 & 0.647 & 0.285 & 0.291 & 0.242 & 0.264 & 0.319 & 1.935 & 3.410 & 3.222 & 2.790 & 2.030 \\
\hline
\end{tabular}


ulus. As Table IV demonistrates, 9 of 11 cases have such decreases. One of the others varies so greatly as to suggest faulty drainage in the catheter. This decrease in filtration is to be expected since constriction of the renal vessels would cut down the blood flow through the glomeruli, and thereby necessarily diminish filtration.

TABLE IV

Glomerular filtration, as per cent of the controls, after cold stimulation in subjects giving blood pressure rises of more than $20 \mathrm{~mm}$. $\mathrm{Hg}_{\mathrm{g}}$

\begin{tabular}{|c|c|c|c|c|c|c|}
\hline Number & $\begin{array}{c}\text { Blood } \\
\text { pressure } \\
\text { rises }\end{array}$ & Control & 1 & 2 & 3 & 4 \\
\hline $\begin{array}{l}23 \mathrm{~L} \ldots \ldots \ldots \\
40 \mathrm{R} \ldots \ldots \\
41 \mathrm{R} \ldots \ldots \ldots \\
43 \mathrm{R} \ldots \ldots \ldots \\
43 \mathrm{~L} \ldots \ldots \ldots \\
44 \mathrm{R} \ldots \ldots \ldots \\
45 \mathrm{R} \ldots \ldots \ldots \\
45 \mathrm{~L} \ldots \ldots \ldots \\
46 \mathrm{~L} \ldots \ldots \ldots \\
39 \mathrm{R} \ldots \ldots \ldots \\
44 \mathrm{~L} \ldots \ldots \ldots\end{array}$ & $\begin{array}{c}m m . H g \\
28 / 42 \\
20 / 34 \\
22 / 15 \\
24 / 20 \\
24 / 20 \\
43 / 45 \\
28 / 22 \\
28 / 22 \\
22 / 20 \\
72 / 75 \\
43 / 45\end{array}$ & $\begin{array}{c}\text { per cent } \\
100 \\
100 \\
100 \\
100 \\
100 \\
100 \\
100 \\
100 \\
100 \\
100 \\
100\end{array}$ & $\begin{array}{r}\text { per cent } \\
85.5 \\
86.4 \\
98.0 \\
60.6 \\
84.8 \\
95.6 \\
69.8 \\
88.8 \\
90.6 \\
216.0 \\
176.0\end{array}$ & $\begin{array}{c}\text { per cent } \\
94.0 \\
82.8 \\
88.0 \\
86.8 \\
50.6 \\
56.3 \\
63.0 \\
91.7 \\
71.8 \\
113.0 \\
160.5\end{array}$ & $\begin{array}{c}\text { per cent } \\
129.0 \\
86.4 \\
89.8 \\
77.4 \\
68.3 \\
93.7 \\
\\
105.0 \\
85.6 \\
100.0 \\
69.3\end{array}$ & $\begin{array}{r}\text { per cent } \\
130.0 \\
85.0 \\
104.7 \\
96.8 \\
56.5 \\
78.7 \\
\\
111.0 \\
73.5 \\
304.0 \\
148.0\end{array}$ \\
\hline Mean of all. & & 100 & 104.7 & 87.1 & 90.4 & 118.8 \\
\hline $\begin{array}{l}\text { Mean of all } \\
\text { but last } 2 .\end{array}$ & & 100 & 84.5 & 76.2 & 92.2 & 92.3 \\
\hline
\end{tabular}

The decreased creatinine excretion, whether apparent or real, throws out the possibility mentioned above, that there were systematic errors in the collection of the urine. There may be incomplete collections, but they are not responsible for the increases found in the excretion of protein. More protein is filtered following the vascular constriction, even though the volume of fluid filtered is decreased.

There seems to be no relation between the degree of blood pressure rise and the amount of proteinuria, the urine volume output, or the glomerular filtration. Of course, it must be borne in mind that the comparison is between different subjects, and not different observations of the same individual.

The right and left kidneys react similarly in practically all cases. This is interesting in view of the fact reported by Sonne (cited by Fishberg (3)), that orthostatic proteinuria arises from the left kidney. However, in the present series of experiments the vascular spasm is presumably general and therefore affects both kidneys. In
Sonne's experiments, the venous return from the left kidney alone was thought to be impaired.

Erlanger and 'Hooker (12), in studying one case of orthostatic proteinuria, found that any factor which lessened the pulse pressure favored the appearance or intensification of the protein excretion. From the blood pressure rises given in Table II, it may 'be seen that in the patients developing proteinuria, 1 had no change in pulse pressure, 9 had an increase, and 12 a decrease. There is a similar distribution among the patients who gave no response in proteinuria (Table I). It would seem, therefore, that changes in pulse pressure, per se, have little influence upon the proteinuria of vascular constriction.

\section{DISCUSSION}

As has been shown above, momentary vascular constriction dependent upon a single variant, if marked enough to give blood pressure rises of more than $16 / 16$, is usually followed closely by an increased excretion of protein in the urine. Perhaps the first question which arises is "how simple is the effect?"

The whole vascular episode, as judged by the blood pressure changes, occurs within 120 seconds. Most of the spastic phase occurs within the first 60 seconds. Hines and Brown (13) suggested that the blood pressure response to the cold stimulus is purely a reflex to peripheral sensory stimulation. The fact that the response is unaffected by the occlusion of the venous return from the chilled hand corroborates this interpretation.

The proteinuria follows very closely upon the vascular constriction. Allowing for the dead space in the kidney, the protein may be said to appear at once. Under the circumstances, it cannot be argued that chilling the skin produces locally a substance which affects the glomerular permeability. The time is too short, and the proteinuria does result even if the venous return from the chilled hand be prevented, as it was in about half the cases in Table II. Apparently, therefore, the proteinuria results from the vascular constriction per se.

It may be of some interest to calculate when the protein must escape from the capillaries, since such a calculation might indicate whether the proteinuria is a primary or secondary effect of the 
vascular spasm. Brodie (18), in computing the force necessary to propel the urine down the renal tubules, has presented the following measurements of the various parts of the dog's nephron. Each dimension cited is the grand average of many measurements made in several dogs. An approximation to the volume capacity of a nephron may be obtained by calculation from the formula for a cylinder, and thus the "dead space" may be roughly estimated (Table V).

TABLE $\nabla$

Dimensions of the dog's nephron, as calculated from Brodie's (18) data

\begin{tabular}{c|c|c|c}
\hline \hline Portion & Length & Diameter & Capacity \\
\hline & mm. & micra & c. mm. \\
Proximal convoluted tubule ... & 11.0 & 12.0 & $\mathbf{0 . 0 0 1 2 4 4}$ \\
Descending loop of Henle..... & 8.5 & 10.0 & 0.000668 \\
Ascending loop of Henle....... & 8.5 & 9.5 & $\mathbf{0 . 0 0 0 5 4 1}$ \\
Distal convoluted tubule....... & 2.0 & 18.0 & $\mathbf{0 . 0 0 0 5 0 9}$ \\
Collecting tubules............. & 22.0 & 12.0 & $\mathbf{0 . 0 0 0 2 3 7}$ \\
\hline Total capacity of nephron and collecting tubule & $\mathbf{0 . 0 0 3 1 9 9}$ \\
\hline
\end{tabular}

This volume capacity of the nephron which we have calculated is widely variable, depending upon the degree of diuresis as Brodie showed, and probably also upon the intrarenal venous blood pressure. Furthermore, errors in the measurement of diameters are squared in the calculation of volume. Brodie's measurements were made in histological sections, and probably do not represent accurately the living condition.

According to Smith's (19) recent review of literature on the kidney, there are about $1,000,000$ nephrons in each human kidney. This gives a value of $3.2 \mathrm{ml}$. as an approximation to the fluid volume capacity of the renal tubules, or " dead space." On the usual assumption that about 60 per cent of the nephrons are active at any given time, one would expect that from the moment that protein appears in the glomerular filtrate until it reaches the pelvis of the kidney, $1.92 \mathrm{ml}$. of protein-free urine must be passed. To this volume we must add $0.35 \mathrm{ml}$, the average capacity of a number 5 catheter, giving a volume of $2.27 \mathrm{ml}$. There is still an undetermined fluid volume between the area cribrosa and the opening of the catheter in the pelvis. Roughly, we might estimate the total dead space, from the glomerulus to the tube in which the urine was collected, as about $3.0 \mathrm{ml}$.
Crude as this calculation may be, there is another consideration which supports the result obtained. Smith, Goldring, and Chasis (20) have noted the time after intravenous injection of phenol red at which the dye appears in the bladder, with different urine flows. When the urine volume output is about one ml. per minute, the dye appears in 200 seconds. Allowing 26 seconds for the circulation time, this gives $2.9 \mathrm{ml}$. as the "dead space" for the human kidney.

These volumes are in excellent agreement with the observed urine volumes in the three cases (32R, 38L, and 40L) where there was no basal proteinuria, and protein did later appear. Measuring from the end of the cold stimulus (at which time the vascular spasm begins to relax) until the beginning of the collection period in which protein appeared in the urine, we find that an average of $2.7 \mathrm{ml}$. of protein-free urine had been collected. The individual volumes were $2.3,2.6$, and $3.1 \mathrm{ml}$. This would indicate that the protein must escape from the capillaries at a time very close to the restoration of the blood flow through the glomerulus, which occurs with the release of the vasospasm.

It is interesting to calculate how much protein leaks through the capillaries, and in what concentration, following the momentary vascular spasm. We shall take two extreme cases from Table II, 32R and 37L. The glomerular filtration for the one kidney will be assumed to be somewhere between 50 and $60 \mathrm{ml}$. per minute. In $32 \mathrm{R}$, with a urine volume of $0.775 \mathrm{ml}$. per minute, the protein concentration in the only specimen to show protein was $36 \mathrm{mgm}$. per cent. The total amount of protein excreted here, following the vascular spasm, was $1.116 \mathrm{mgm}$. The urine was concentrated from 65 to 78 times, say 72. Therefore the concentration of protein in the glomerular filtrate was $36 / 72=0.50 \mathrm{mgm}$. per $100 \mathrm{ml}$. In $37 \mathrm{~L}$ the basal proteinuria was high-362 mgm. per cent, and rose to $816 \mathrm{mgm}$. per cent after the cold stimulus, an increase of $454 \mathrm{mgm}$. per cent. The urine volumes were 0.35 and $0.25 \mathrm{ml}$. per minute, giving concentration ratios of about 150 and 210 . Therefore, the concentrations of protein in the glomerular filtrate, before and after the cold stimulus, would be 2.42 and $3.88 \mathrm{mgm}$. per cent, an increased 
protein leakage into the glomerular filtrate of about $1.46 \mathrm{mgm}$. per $100 \mathrm{ml}$.

From the calculation, it is seen that the effect of the momentary spasm upon the capillary permeability is not really very marked. It appears to be greater because of the fact that the fluid filtered by the capillaries is concentrated many times over by the kidney tubules. Apparently the factor which causes the proteinuria is a sudden intensification of the vascular constriction. Severely hypertensive patients may have proteinfree urines, and in several of our cases moderate hypertensions without proteinuria were observed. When, however, the blood pressure was abruptly driven up from whatever basal level, proteinuria appeared. This was observed by us in a man who has had a hypertension of several years' duration. In his case, voided urines were used, and the vascular constriction was produced by having him walk about after a half hour's rest. The basal blood pressure was 150/110; after walking about it was 208/138. Meanwhile the urine, which was protein-free in the rest period, suddenly showed protein (4 mgm. per cent), and the volume output fell by about 50 per cent. The proteinuria which appeared was slight, possibly because of the renal vascular sclerosis. Such sclerosis is probable in this case since the urinary specific gravity is fixed at 1.010. Conceivably, in hypertension the capillaries are either not markedly anoxic or have become adjusted, as judged by their permeability, to the existing degree of anoxia. When further constriction is superimposed with reduction in blood flow and oxygen supply, the permeability becomes impaired and protein leakage ensues.

One possible criticism of the results may be mentioned here. Ureteral catheterization, in some subjects, causes a transitory proteinuria (3). Since such catheterizations were part of the routine procedure, it should be emphasized that the patients were returned to bed after catheterization, and left there for at least $\mathbf{3 0}$ minutes before beginning the test. Furthermore, two control urine specimens were obtained from each ureteral catheter before the cold stimulus was given.

SUMMARY AND CONCLUSIONS

Forty-seven subjects were used in a study of the relation of proteinuria to vasospasm. The subjects were women ranging from the third month of pregnancy to the ninth month after delivery. Some had normal pregnancies, some toxic. Some had a preexisting proteinuria, others had not; some had demonstrable renal disease, while the majority had not.

Urine was collected at short intervals from ureteral catheters, during which time vasospasm was produced by immersing one hand in ice water for one minute. As a result of this procedure, the vascular constriction appears and disappears within 120 seconds.

Twenty-four patients showed no increase in urinary protein excretion following the cold stimulus. With two exceptions, none of these had rises in blood pressure of more than $16 / 16 \mathrm{~mm}$. $\mathrm{Hg}$; that is, vasospasm was slight. These patients are regarded as the control series.

Twenty-three patients responded with an increased excretion of urinary protein immediately following the cold stimulus. All of these subjects showed blood pressure rises of more than $16 / 16$ $\mathrm{mm} . \mathrm{Hg}$; that is, vasospasm was definitely produced.

The increased proteinuria of the second series actually occurs, as shown by the protein excretion /creatinine excretion ratio. This ratio indicates that after vascular constriction more protein escapes per unit of glomerular filtration. Incomplete collections of urine volume would not vitiate the conclusion drawn from this ratio.

The right and left kidney usually reacted similarly. In a few cases one kidney showed increased proteinuria while the other did not.

Changes in pulse pressure apparently do not influence the appearance of proteinuria induced by the cold stimulus.

It is concluded from the promptness of reaction, independence of venous return from the chilled hand, and from calculations of the renal tubular volume capacity, that the proteinuria begins with the release of the vascular spasm.

We are indebted to Drs. S. A. Cosgrove, J. F. Norton, and E. G. Waters for their permission to use patients from their services. Dr. Cosgrove also read and criticized the typescript. Some of the ureteral catherizations were done by Dr. Dana Cox and Dr. E. W. Cartwright. Most of the patients giving marked blood pressure responses to the cold pressor test were selected by Mrs. E. R. Chesley from her large clinic series. 


\section{BIBLIOGRAPHY}

1. Senator, H., Die Albuminurie in physiologischer und klinischer Beziehung und ihre Behandlung. August Hirschwald, Berlin, 1890, 2d ed.

2. Volhard, F., Nieren und Ableitende Harnwege. VI. Die Albuminurie. Handb. d. inn. Med., Julius Springer, Berlin, 1931, 6, part I, 812.

3. Fishberg, A. M., Hypertension and Nephritis, Lea and Febiger, Philadelphia, 1934, 3d ed.

4. Johnson, G., Latent albuminuria: its etiology and pathology. Brit. M. J., 1879, 2, 928.

5. Abesser, Sportärtziche Beobachtungen bei der Schutzpolizei. München. med. Wchnschr., 1926, 73, 1697.

6. Christensen, H. B., Untersuchungen des Urinsedimentes von Sportsleuten und Nephritikern. Deutsches Arch. f. klin. Path., 1909, 98, 379.

7. Wertheim, De l'influence de la Refrigeration de la Peu sur la Circulation du Rein. Arch. d. Path., 1894, 308. (Cited by Schlombka (9).)

8. Jehle, L., Die Albuminurie. Klinische und experimentelle Beiträge zur Frage der orthostatischlordotischen und der nephritischen Albuminurie. Julius Springer, Berlin, 1914.

9. Schlombka, G., Untersuchungen über den Einfluss äusserer Abkühlungen auf die Nierentätigkeit. Ztschr. f. d. ges. exper. Med., 1928, 61, 405.

10. Starr, I., The production of albuminuria by renal vasoconstriction in animals and in man. J. Exper. Med., 1926, 43, 31.

11. Hermann, M., Sitzungber. k. akad. Wissensch., Math.Naturwissensch. cl., Wien, 1862, 45, part 2, 317. (Cited by Starr (10).)

12. Erlanger, J., and Hooker, D. R., An experimental study of blood pressure and of pulse pressure in man, including a consideration (c) of the relation between blood pressure and pulse pressure and the output of albumin in a case of orthostatic albuminuria. Johns Hopkins Hosp. Rep., 1904, 12, 346.

13. Hines, E. A., and Brown, G. E., A standard test for measuring the variability of blood pressure: its significance as an index of the prehypertensive state. Ann. Int. Med., 1933, 7, 209.

14. Chesley, L. C., and Chesley, E. R., The cold pressor test as a means of predicting toxemia of pregnancy. (In preparation.)

15. Peters, J. P., and Van Slyke, D. D., Quantitative Clinical Chemistry. Vol. II. Methods. Williams and Wilkins Co., Baltimore, 1932, pp. 528 and 682 .

16. Miller, B. F., and Winkler, A. W., The renal excretion of endogenous creatinine in man. Comparison with exogenous creatinine and inulin. J. Clin. Invest., 1938, 17, 31.

17. Hawk, P. B., and Bergeim, O., Practical Physiological Chemistry. Blakiston's Sons, Philadelphia, 1931, 10th ed., pp. 421 and 835.

18. Brodie, T. G., A new conception of the glomerular function. Proc. Roy. Soc. London, s. B., 1913, 87, 571.

19. Smith, H. W., The Physiology of the Kidney. Oxford University Press, New York, 1937, pp. 67 and 262.

20. Smith, H. W., Goldring, W., and Chasis, H., The measurement of the tubular excretory mass, effective blood flow and filtration rate in the normal human kidney. J. Clin. Invest., 1938, 17, 263. 